\title{
Long-term Favorable Outcomes of Radiofrequency Ablation for Hepatocellular Carcinoma as an Initial Treatment: A Single-center Experience Over a 10-Year Period
}

\author{
MASAYO TSUKAMOTO, YO-ICHI YAMASHITA, KATSUNORI IMAI, NAOKI UMEZAKI, \\ TAKANOBU YAMAO, TAKAYOSHI KAIDA, KOSUKE MIMA, SHIGEKI NAKAGAWA, \\ DAISUKE HASHIMOTO, AKIRA CHIKAMOTO, TAKATOSHI ISHIKO and HIDEO BABA \\ Department of Gastroenterological Surgery, \\ Kumamoto University Graduate School of Life Sciences, Kumamoto, Japan
}

\begin{abstract}
Background: Radiofrequency ablation (RFA) is an alternative to hepatic resection and one of the major therapeutic options for hepatocellular carcinoma (HCC). Here, we investigated the long-term outcomes of RFA as an initial treatment for HCC. Patients and Methods: From January 2000 to December 2014, we treated 1,043 patients with RFA for HCC at the Kumamoto University Hospital; 327 of these patients (31.4\%) were treated for primary HCC. After exclusion of 75 patients who underwent combined therapy, data for 252 patients were examined. We retrospectively analyzed the long-term outcomes of RFA and identified factors of poor prognosis. Results: The median platelet count, prothrombin activity and indocyanine green retention rate at $15 \mathrm{~min}$ were $9.1 \times 10^{4} / \mu \mathrm{l}, 83 \%$ and $26 \%$, respectively. The 5year overall survival (OS) rate was $69 \%$ and the median survival time was 7.0 years. The 5-year recurrence-free survival (RFS) rate was $17 \%$, and the median RFS was 2.0 years. A multivariate analysis revealed that age $>80$ years [hazard ratio $(H R)=7.76, p=0.011]$, tumor diameter $>2 \mathrm{~cm}$ $(H R=1.68, p=0.047)$ and multiple tumors $(H R=1.87, p=0.014)$ were independent prognostic factors for poor OS. For RFS, des- $\gamma$-carboxy prothrombin $(D C P) \geq 40 \mathrm{mAU} / \mathrm{ml}(\mathrm{HR}=1.47$, $p=0.038)$ and multiple tumors $(H R=1.63, p=0.0056)$ were independent prognostic factors. Local recurrence at the ablated site occurred in 33/252 patients (13\%), and in 33/372 tumors (8.9\%). Conclusion: Although our cohort included patients
\end{abstract}

Correspondence to: Hideo Baba, MD, Ph.D., FACS, Department of Gastroenterological Surgery, Kumamoto University Graduate School of Medical Sciences 1-1-1 Honjo, Kumamoto, 860-8556, Japan. Tel: +81 963735212, Fax: +81 963714378, e-mail: hdobaba@kumamoto-u.ac.jp

Key Words: Radiofrequency ablation, hepatocellular carcinoma, long-term outcomes. with relatively worse liver function, a favorable 5-year survival rate $69 \%$ was obtained by RFA. DCP $\geq 40 \mathrm{mAU} / \mathrm{ml}$ and multiple HCCs contribute to a higher risk of recurrence. Patients with these factors should therefore be followed-up intensively.

Hepatocellular carcinoma (HCC) is the fifth most common cancer in the world (1). Many treatments are now available for HCC, including hepatic resection, local ablation therapy, transcatheter hepatic arterial chemoembolization (TACE), and transplantation (2). Local ablation such as radiofrequency ablation (RFA), microwave coagulation and percutaneous ethanol injection play important roles in the management of HCC (3). Hepatic resection or RFA is recommended for $\mathrm{HCCs}$ with a diameter of $\leq 3 \mathrm{~cm}$ in patients with good liver functional reserve, according to the guidelines established by the American Association for the Study of the Liver Disease (4), the European Association for the Study of the Liver (5) and Japanese evidence-based guidelines $(6,7)$

RFA is becoming an alternative therapy for small HCC tumors $(\leq 3 \mathrm{~cm})$ because it is efficient and has an extremely low associated mortality rate, and it is much less invasive than hepatic resection $(8,9)$. The 5-year overall survival (OS) rate after percutaneous RFA of small HCCs is reported to be comparable to that of hepatic resection $(7,10-12)$. However, relatively high local recurrence rates of $\mathrm{HCC}$ following RFA have been reported, with 1-year local recurrence rates ranging from $9.7 \%$ to $15.0 \%$ and 3 -year local recurrence rates ranging from $19 \%$ to $27 \%$ (13-16). It was also reported that $12.5 \%$ of a series of patients with HCC showed biopsy-proven needle-track seeding 4-18 months after RFA, and intrahepatic dissemination after RFA could be a serious problem (17-19). It is thus important to evaluate long-term outcomes and identify risk factors for recurrence after RFA for HCC. 
Here we retrospectively examined the long-term outcomes after RFA as initial treatment for patients with HCC with relatively unlimited tumor size and liver function, and identified factors of poor prognosis in the patients.

\section{Patients and Methods}

Patients. From January 2000 to December 2014, we treated 1043 patients with RFA for HCC at Kumamoto university hospital. Of these patients, 327 (31.4\%) were treated for primary HCC. Seventyfive patients $(22.9 \%)$ were excluded from the study because they had undergone RFA combined with therapies such as hepatic resection (67 patients), microware coagulation (one patient) and percutaneous ethanol injection (eight patients). Thus, a final total of 252 patients were examined. The median follow-up time of this patient series was 41 months.

RFA procedures. When a patient's tumor was not close to the liver surface and was detected by percutaneous ultrasonography, percutaneous ultrasonography-guided RFA was selected. When the tumor was located on the liver surface or was undetectable by percutaneous ultrasonography, laparoscopic RFA or RFA with laparotomy was selected (20). When the tumor was located near the hepatic dome and was undetectable by percutaneous ultrasonography, thoracoscopic RFA or RFA with thoracotomy was selected (20). When tumors were multiple and located on the liver surface or deeper, percutaneous and laparoscopic or thoracoscopic RFA were combined.

For tumor ablation, an electrode with a 2- to 3-cm exposed tip (Radionics, Burlington, MA, USA) connected to a $500-\mathrm{kHz}$ RF Generator (Radionics) was used. A tip temperature of $10-20^{\circ} \mathrm{C}$ was maintained by chilled saline solution infusion via a peristaltic pump. After electrode insertion into the lesion, we gradually increased the power to $60 \mathrm{~W}$ in a $2-\mathrm{cm}$-long needle or $80 \mathrm{~W}$ in a $3-\mathrm{cm}-1$ long needle at the rate of $20 \mathrm{~W} / \mathrm{min}$. After ablation exposure, we stopped the pump and measured the temperature of the needle tip. To achieve an accurate and wide tumor margin, we ablated not only the tumor nodule, but also the area surrounding the tumor, especially if the target nodule was $>2 \mathrm{~cm}$ in diameter. Enhanced computed tomography (CT) was performed 7 days after RFA to evaluate the tumor response to RFA in all patients. Complete ablation was defined as the absence of contrast enhancement within the entire tumor. The procedure was repeated if an unablated tumor remnant was suspected.

Statistical analysis. Continuous variables are expressed as means \pm standard deviation (SD) and were compared using Student's $t$-test. Categorical variables were compared using either the chi-squared test or Fisher's exact test, as appropriate. Any death that occurred in the hospital after RFA was recorded as a mortality. Grade III-V complications of Clavien-Dindo classification (21) were recorded as morbidity. The OS and RFS curves were generated by the Kaplan-Meier method and compared by the log-rank test. We subjected variables that exhibited a probability value of less than 0.05 in a univariate analysis to a multivariate analysis using the Cox proportional hazards model. All analyses were performed with JMP ${ }^{\circledR}$ Pro 9.0.2 (SAS, Cary, NC). $p$-Values of less than 0.05 were considered significant.
Table I. Clinical characteristics of our cohort. Data are the mean $\pm S D$ or number.

\begin{tabular}{lc}
\hline Characteristic & $\mathrm{n}=252$ \\
\hline Age, years & $68 \pm 8.3$ \\
Gender: Male:female & $150: 102$ \\
HBV/HCV/nonB nonC & $27: 189: 38$ \\
Albumin $(\mathrm{g} / \mathrm{dl})$ & $3.6 \pm 0.5$ \\
T-Bil $(\mathrm{mg} / \mathrm{dl})$ & $0.9 \pm 0.5$ \\
Plt $\left(10^{4} / \mu \mathrm{l}\right)$ & $9.1 \pm 7.2$ \\
PT $(\%)$ & $83 \pm 15$ \\
Liver damage A/B/C & $116 / 97 / 16$ \\
ICG R15 (\%) & $26 \pm 15$ \\
LHL15 & $0.85 \pm 0.07$ \\
\hline
\end{tabular}

HBV: Hepatitis B virus; HCV: hepatitis C virus; T-bil: total bilirubin; Plt: platelet; PT: prothrombin time; ICG R15: indocyanine green retention rate at $15 \mathrm{~min}$; LHL15: uptake rate of the liver plus heart at $15 \mathrm{~min}$.

Table II. Tumor-related and surgical factors of our cohort. Data are the mean $\pm S D$ or number.

\begin{tabular}{lc}
\hline Factor & $\mathrm{n}=252$ \\
\hline AFP (ng/ml) & $18.8 \pm 570$ \\
AFP-L3 (\%) & $0.5 \pm 14$ \\
DCP (mAU/ml) & $25 \pm 1333$ \\
Tumor size (cm) & $2 \pm 0.8$ \\
Tumor number (single/multiple) & $162: 77$ \\
Percutaneus/laparoscopic or thoracoscopic/open & $148: 104: 16$ \\
Operation time (min) & $145 \pm 100$ \\
Bleeding (g) & $5 \pm 95$ \\
\hline
\end{tabular}

AFP: Alpha-fetoprotein; AFP-L3: Lens culinaris agglutinin-reactive fraction of AFP; DCP: des- $\gamma$-carboxy prothrombin.

\section{Results}

Patient clinicopathological characteristics. The clinical characteristics of our cohort are summarized in Table I. The median age was 68 years. The ratio of men to women was 3 to 2. The tumor-related and surgical factors of our cohort are summarized in Table II. The median tumor size was $2(0.5-$ $6.7) \mathrm{cm}$. The numbers of single- and multiple-HCC were 162 and 77 patients, respectively. We treated a maximum of 10 tumors at one time.

Prognostic factors related to OS and RFS. The survival curves related to OS and RFS are illustrated in Figure 1. The 5 - year OS rate was $69 \%$, and the median survival time was 7.0 years. The 5-year RFS rate was $17 \%$, and the median recurrence-free survival time was 2.0 years.

The univariate analysis revealed the following as factors of poor prognosis for OS: age $>80$ years, alpha-fetoprotein 
a

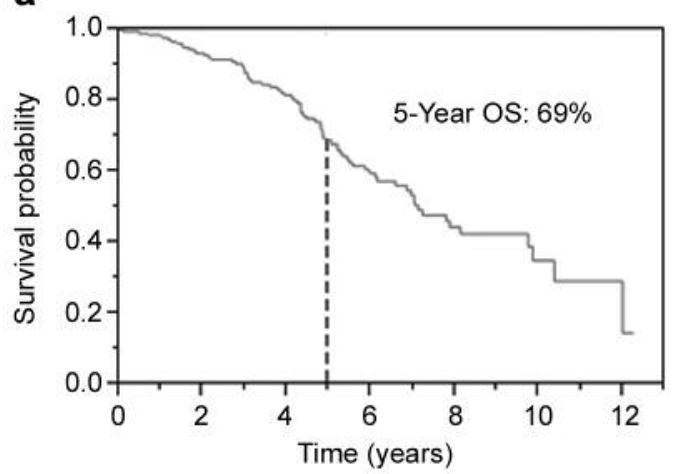

b

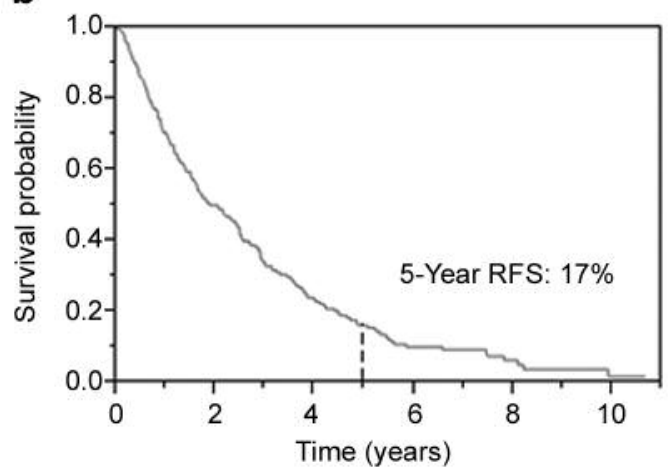

Figure 1. (a) The overall survival (OS) after radiofrequency ablation for primary hepatocellular carcinoma. The 5-year OS was 69\%. (b) The recurrence-free survival (RFS) after radiofrequency ablation for primary hepatocellular carcinoma. The 5-year RFS was $17 \%$.

(AFP) $\geq 10 \mathrm{ng} / \mathrm{ml}$, Lens culinaris agglutinin-reactive fraction of AFP (AFP-L3) $\geq 0.6 \%$, des- $\gamma$-carboxy prothrombin (DCP) $\geq 40 \mathrm{mAU} / \mathrm{ml}$, tumor diameter $>2 \mathrm{~cm}$ and multiple tumors (Table III). The multivariate analysis revealed that age $>80$ years [hazard ratio $(\mathrm{HR})=7.76, p=0.011$ ], tumor diameter $>2 \mathrm{~cm}(\mathrm{HR}=1.68, p=0.047)$, and multiple tumors (HR=1.87, $p=0.014)$ were independent factors of poor prognosis for OS (Table IV).

For RFS, albumin $<4.1 \mathrm{~g} / \mathrm{dl}$, AFP $\geq 10 \mathrm{ng} / \mathrm{ml}$, AFP-L3 $\geq 0.6 \%$, DCP $\geq 40 \mathrm{mAU} / \mathrm{ml}$, and multiple tumors were identified as factors of poor prognosis in the univariate analysis (Table V). The multivariate analysis showed that $\mathrm{DCP} \geq 40 \mathrm{mAU} / \mathrm{ml}(\mathrm{HR}=1.47, p=0.038)$ and multiple tumors (HR=1.63, $p=0.0056)$ were independent factors of poor prognosis for RFS (Table VI).

Prognostic factors related to local recurrence. We defined local recurrence after RFA as tumor recurrence in or on the ablation sites. Local recurrence at the ablated site occurred in 33 patients (13\%), in other words, 33 out of a total of $372 \mathrm{HCCs}$ $(8.9 \%)$. After recurrence, 13 patients (39\%) were treated with
Table III. Univariate analysis of factors related to overall survival.

\begin{tabular}{|c|c|c|c|}
\hline Factor & $\mathrm{n}$ & 5 -Year survival $(\%)$ & $p$-Value \\
\hline \multicolumn{4}{|l|}{ Gender } \\
\hline Male & 150 & 66.7 & \multirow[t]{2}{*}{0.26} \\
\hline Female & 102 & 72.8 & \\
\hline \multicolumn{4}{|l|}{ Age } \\
\hline$<80$ years & 239 & 72.0 & \multirow[t]{2}{*}{0.0002} \\
\hline$\geq 80$ years & 13 & 0.0 & \\
\hline \multicolumn{4}{|l|}{ Albumin } \\
\hline$<4.1 \mathrm{~g} / \mathrm{dl}$ & 207 & 77.9 & \multirow[t]{2}{*}{0.27} \\
\hline$\geq 4.1 \mathrm{~g} / \mathrm{dl}$ & 45 & 66.8 & \\
\hline \multicolumn{4}{|l|}{ T-Bil } \\
\hline$<1.5 \mathrm{mg} / \mathrm{dl}$ & 210 & 68.1 & \multirow[t]{2}{*}{0.17} \\
\hline$\geq 1.5 \mathrm{mg} / \mathrm{dl}$ & 41 & 74.3 & \\
\hline \multicolumn{4}{|l|}{ Plt } \\
\hline$<10 \times 10^{4} / \mu 1$ & 123 & 65.0 & \multirow[t]{2}{*}{0.18} \\
\hline$\geq 10 \times 10^{4} / \mu \mathrm{l}$ & 127 & 72.5 & \\
\hline \multicolumn{4}{|l|}{ PT } \\
\hline$<90 \%$ & 171 & 65.4 & \multirow[t]{2}{*}{0.21} \\
\hline$\geq 90 \%$ & 81 & 71.2 & \\
\hline \multicolumn{4}{|l|}{ Liver damage } \\
\hline $\mathrm{A}$ & 116 & 71.0 & \multirow[t]{3}{*}{0.97} \\
\hline $\mathrm{B}$ & 97 & 63.9 & \\
\hline $\mathrm{C}$ & 16 & 50 & \\
\hline \multicolumn{4}{|l|}{ ICG R15 } \\
\hline$<10 \%$ & 14 & 80 & \multirow[t]{2}{*}{0.075} \\
\hline$\geq 10 \%$ & 200 & 67.6 & \\
\hline \multicolumn{4}{|l|}{ LHL15 } \\
\hline$<0.9$ & 171 & 68.0 & \multirow[t]{2}{*}{0.48} \\
\hline$\geq 0.9$ & 64 & 73.0 & \\
\hline \multicolumn{4}{|l|}{ AFP } \\
\hline$<10 \mathrm{ng} / \mathrm{ml}$ & 90 & 79.0 & \multirow[t]{2}{*}{0.032} \\
\hline$\geq 10 \mathrm{ng} / \mathrm{ml}$ & 156 & 65.2 & \\
\hline \multicolumn{4}{|l|}{ AFP-L3 } \\
\hline$<0.6 \%$ & 171 & 74 & \multirow[t]{2}{*}{0.016} \\
\hline$\geq 0.6 \%$ & 74 & 61 & \\
\hline DCP & & & \\
\hline$<40 \mathrm{mAU} / \mathrm{ml}$ & 176 & 76.4 & 0.0010 \\
\hline$\geq 40 \mathrm{mAU} / \mathrm{ml}$ & 74 & 49.5 & \\
\hline Tumor size & & & \\
\hline$<2 \mathrm{~cm}$ & 113 & 78 & 0.0070 \\
\hline$\geq 2 \mathrm{~cm}$ & 138 & 61 & \\
\hline Tumor number & & & \\
\hline Single & 162 & 74 & 0.0036 \\
\hline Multiple & 77 & 55 & \\
\hline Operation time & & & \\
\hline$<145 \min$ & 120 & 74.1 & 0.081 \\
\hline$\geq 145 \mathrm{~min}$ & 122 & 62.0 & \\
\hline Bleeding & & & \\
\hline$<10 \mathrm{~g}$ & 176 & 71.4 & 0.23 \\
\hline$\geq 10 \mathrm{~g}$ & 51 & 55.1 & \\
\hline
\end{tabular}

T-bil: Total bilirubin; Plt: platelet; PT: prothrombin time; ICG R15: indocyanine green retention rate at $15 \mathrm{~min}$; LHL15: uptake rate of the liver plus heart at $15 \mathrm{~min}$; AFP: alpha-fetoprotein; AFP-L3: Lens culinaris agglutinin-reactive fraction of AFP; DCP: des- $\gamma$-carboxy prothrombin.

RFA again, 13 patients (39\%) with TACE, two patients (6\%) with hepatic resection, one (3\%) with radiotherapy, and four patients $(12 \%)$ were provided only best supportive care. The 
Table IV. Multivariate analysis of factors related to overall survival.

\begin{tabular}{lccc}
\hline Factor & HR & $95 \% \mathrm{CI}$ & $p$-Value \\
\hline Age $\geq 80$ years & 7.76 & $1.58-42.4$ & 0.011 \\
Tumor size $\geq 2 \mathrm{~cm}$ & 1.68 & $1.01-2.88$ & 0.047 \\
Multiple tumors & 1.87 & $1.14-3.07$ & 0.014 \\
AFP $\geq 10 \mathrm{ng} / \mathrm{ml}$ & 1.37 & $0.73-2.64$ & 0.33 \\
AFP-L3 $\geq 0.6 \%$ & 1.50 & $0.85-2.64$ & 0.16 \\
DCP $\geq 40 \mathrm{mAU} / \mathrm{ml}$ & 1.75 & $0.99-3.01$ & 0.052 \\
\hline
\end{tabular}

AFP: Alpha-fetoprotein; AFP-L3: Lens culinaris agglutinin-reactive fraction of AFP; DCP: des- $\gamma$-carboxy prothrombin.

univariate analysis revealed DCP $\geq 40 \mathrm{mAU} / \mathrm{ml}$ as the significant predictive factor for local recurrence $(p=0.0039)$.

\section{Discussion}

The median follow-up time in this study, 41 months, was long compared to the 10.4-38.3 months in previous studies $(1,2$, $7,22-24)$. Our finding of a favorable long-term outcome, i.e. 5 -year OS rate of $69.0 \%$, was obtained although our cohort included patients with relatively poor liver functional reserve such as liver damage grade B (97 patients, $42 \%)$ and C (16 patients, 7\%) $(1,2,7,22,24)$. Other studies have reported lower 5-year OS rates after RFA for HCC, i.e. 59.4-61.1\% (7, $22,24)$. In two of those studies, the 2- and 5-year RFS rates were reported to be $44.6-69.3 \%$ and $23.9-28.3 \%$, respectively $(7,22)$. In the present study, the 2-year RFS rate was $51.5 \%$ although tumor diameter was $>3 \mathrm{~cm}$ in 26 patients $(10.3 \%)$ and $11(4.4 \%)$ patients had more than three tumors. We believe that the 2-year RFS rate similar to those of previous studies indicates that the efficacy of RFA in the local control of HCC was good in our cohort. The relatively worse 5-year RFS rate in our cohort suggests that more patients with multicentric recurrences were included.

The albumin value (1), tumor diameter $>2 \mathrm{~cm}$, multiple tumors, AFP $\geq 15 \mathrm{ng} / \mathrm{ml}$, AFP-L3 $>15 \%$, DCP $\geq 40 \mathrm{mAU} / \mathrm{ml}$, age, hepatitis $\mathrm{C}$ virus positivity and Child-Pugh score B (2, 24) have been reported as independent prognostic factors for OS in patients with HCC. Here, we identified age $>80$ years, tumor diameter $>2 \mathrm{~cm}$, and multiple tumors as independent factors of poor prognosis for OS, and DCP $\geq 40 \mathrm{mAU} / \mathrm{ml}$ and multiple tumors as those for RFS. We have reported that the RFS and OS rates were significantly worse after RFA than after hepatic resection in cases of $\mathrm{HCC}>2 \mathrm{~cm}$, whereas there were no significant differences in patients with HCCs $\leq 2 \mathrm{~cm}$ (7). Therefore, RFA would not be a good treatment option for patients with HCCs larger than $2 \mathrm{~cm}$.

We also reported that patients with a high DCP level $(>100 \mathrm{mAU} / \mathrm{ml})$ are at risk for microinvasion even for those with HCCs $\leq 2 \mathrm{~cm}$ (25). Tumor size and the value of DCP can be confirmed before the treatment decision is made, and
Table V. Univariate analysis of factors related to recurrence-free survival.

\begin{tabular}{|c|c|c|c|}
\hline Factor & $\mathrm{n}$ & 5-Year RFS(\%) & $p$-Value \\
\hline \multicolumn{4}{|l|}{ Gender } \\
\hline Male & 150 & 17 & \multirow[t]{2}{*}{0.31} \\
\hline Female & 102 & 16.7 & \\
\hline \multicolumn{4}{|l|}{ Age } \\
\hline$<80$ years & 239 & 17.5 & \multirow[t]{2}{*}{0.57} \\
\hline$\geq 80$ years & 13 & 0.0 & \\
\hline \multicolumn{4}{|l|}{ Albumin } \\
\hline$<4.1 \mathrm{~g} / \mathrm{dl}$ & 207 & 13.8 & \multirow[t]{2}{*}{0.0052} \\
\hline$\geq 4.1 \mathrm{~g} / \mathrm{dl}$ & 45 & 30 & \\
\hline \multicolumn{4}{|l|}{ T-Bil } \\
\hline$<1.5 \mathrm{mg} / \mathrm{dl}$ & 210 & 17 & \multirow[t]{2}{*}{0.72} \\
\hline$\geq 1.5 \mathrm{mg} / \mathrm{dl}$ & 41 & 17 & \\
\hline \multicolumn{4}{|l|}{ Plt } \\
\hline$<10 \times 10^{4} / \mu 1$ & 123 & 18 & \multirow[t]{2}{*}{0.87} \\
\hline$\geq 10 \times 10^{4} / \mu \mathrm{l}$ & 127 & 17 & \\
\hline \multicolumn{4}{|l|}{ PT } \\
\hline$<90 \%$ & 171 & 16.7 & \multirow[t]{2}{*}{0.98} \\
\hline$\geq 90 \%$ & 81 & 19 & \\
\hline \multicolumn{4}{|l|}{ Liver damage } \\
\hline A & 116 & 21 & \multirow[t]{3}{*}{0.52} \\
\hline B & 97 & 12 & \\
\hline $\mathrm{C}$ & 16 & 21 & \\
\hline \multicolumn{4}{|l|}{ ICG R15 } \\
\hline$<10 \%$ & 14 & 20 & \multirow[t]{2}{*}{0.19} \\
\hline$\geq 10 \%$ & 200 & 17.2 & \\
\hline \multicolumn{4}{|l|}{ LHL15 } \\
\hline$<0.9$ & 171 & 17 & \multirow[t]{2}{*}{0.57} \\
\hline$\geq 0.9$ & 64 & 17 & \\
\hline \multicolumn{4}{|l|}{ AFP } \\
\hline$<10 \mathrm{ng} / \mathrm{ml}$ & 90 & 24 & \multirow[t]{2}{*}{0.027} \\
\hline$\geq 10 \mathrm{ng} / \mathrm{ml}$ & 156 & 13 & \\
\hline \multicolumn{4}{|l|}{ AFP-L3 } \\
\hline$<0.6 \%$ & 171 & 20 & \multirow[t]{2}{*}{0.057} \\
\hline$\geq 0.6 \%$ & 74 & 12 & \\
\hline DCP & & & \\
\hline$<40 \mathrm{mAU} / \mathrm{ml}$ & 176 & 20.8 & 0.0077 \\
\hline$\geq 40 \mathrm{mAU} / \mathrm{ml}$ & 74 & 9 & \\
\hline Tumor size & & & \\
\hline$<2 \mathrm{~cm}$ & 113 & 17 & 0.70 \\
\hline$\geq 2 \mathrm{~cm}$ & 138 & 17 & \\
\hline Tumor number & & & \\
\hline Single & 162 & 19 & 0.0093 \\
\hline Multiple & 77 & 12 & \\
\hline Operation time & & & \\
\hline$<145 \min$ & 120 & 20.3 & 0.27 \\
\hline$\geq 145 \mathrm{~min}$ & 122 & 11 & \\
\hline Bleeding & & & \\
\hline$<10 \mathrm{~g}$ & 176 & 16.9 & 0.93 \\
\hline$\geq 10 \mathrm{~g}$ & 51 & 11.9 & \\
\hline
\end{tabular}

T-bil: Total bilirubin; Plt: platelet; PT: prothrombin time; ICG R15: indocyanine green retention rate at $15 \mathrm{~min}$; LHL15: uptake rate of the liver plus heart at $15 \mathrm{~min}$; AFP: alpha-fetoprotein; AFP-L3: Lens culinaris agglutinin-reactive fraction of AFP; DCP: des- $\gamma$-carboxy prothrombin.

we therefore recommend that hepatic resection, not RFA, be performed in cases of HCC larger than $2 \mathrm{~cm}$ and for patients with a DCP value $\geq 40 \mathrm{mAU} / \mathrm{ml}$. 
Table VI. Multivariate analysis of factors related to recurrence-free survival.

\begin{tabular}{lccc}
\hline Factor & HR & $95 \%$ CI & $p$-Value \\
\hline DCP $\geq 40 \mathrm{mAU} / \mathrm{ml}$ & 1.47 & $1.02-2.08$ & 0.038 \\
Multiple tumors & 1.63 & $1.16-2.27$ & 0.0056 \\
Albumin $<4.1 \mathrm{~g} / \mathrm{dl}$ & 1.48 & $0.98-2.30$ & 0.060 \\
AFP $\geq 10 \mathrm{ng} / \mathrm{ml}$ & 1.20 & $0.81-1.79$ & 0.38 \\
AFP-L3 $\geq 0.6 \%$ & 1.26 & $0.86-1.84$ & 0.24 \\
\hline
\end{tabular}

AFP: Alpha-fetoprotein; AFP-L3: Lens culinaris agglutinin-reactive fraction of AFP; DCP: des- $\gamma$-carboxy prothrombin.

The limitations of this study include its retrospective and single-center design. We need to confirm our outcomes in more patients in multiple centers and compare our RFA outcomes to those obtained with hepatic resection and TACE. We are now registering our patients in and expecting the results of the Efficacy of Surgery $v s$. Radiofrequency A blation on Primary Hepatocellular Carcinoma (SURF) trial (26).

In conclusion, favorable prognosis, i.e. 69\% 5-year survival rate, was obtained by RFA although our cohort included patients with poor liver function. Patients with DCP values $\geq 40 \mathrm{mAU} / \mathrm{ml}$ or multiple HCCs have a higher risk of recurrence, and clinicians should therefore choose RFA, hepatic resection or other treatments in a thoughtful manner and provide an intensive follow-up, especially for such patients.

\section{Conflicts of Interest}

The Authors declare they have no conflict of interest in regard to this study.

\section{Ethical approval}

All procedures performed in studies involving human participants were in accordance with the ethical standards of the institutional and/or national research committee and with the 1964 Helsinki declaration and its later amendments or comparable ethical standards.

Informed consent: Informed consent was obtained from all individual participants included in the study.

\section{References}

1 Chen MS, Li JQ, Zheng Y, Guo RP, Liang HH, Zhang YQ, Lin $\mathrm{XJ}$ and Lau WY: A prospective randomized trial comparing percutaneous local ablative therapy and partial hepatectomy for small hepatocellular carcinoma. Ann Surg 243(3): 321-328, 2006.

2 Hasegawa K, Makuuchi M, Takayama T, Kokudo N, Arii S, Okazaki M, Okita K, Omata M, Kudo M, Kojiro M, Nakanuma Y, Takayasu K, Monden M, Matsuyama Y and Ikai I: Surgical resection $v s$. percutaneous ablation for hepatocellular carcinoma: A preliminary report of the japanese Nationwide Survey. J Hepatol 49(4): 589-594, 2008.

3 Imai K, Beppu T, Chikamoto A, Mima K, Okabe H, Hayashi H, Nitta $\mathrm{H}$, Ishiko $\mathrm{T}$ and Baba $\mathrm{H}$ : Salvage treatment for local recurrence of hepatocellular carcinoma after local ablation therapy. Hepatol Res 44(14): E335-345, 2014.

4 Bruix J and Sherman M: Management of hepatocellular carcinoma. Hepatology 42(5): 1208-1236, 2005.

5 Bruix J, Sherman M, Llovet JM, Beaugrand M, Lencioni R, Burroughs AK, Christensen E, Pagliaro L, Colombo M and Rodes J: Clinical management of hepatocellular carcinoma. Conclusions of the BARCELONA-2000 EASL conference. European association for the study of the liver. J Hepatol 35(3): 421-430, 2001.

6 Makuuchi M, Kokudo N, Arii S, Futagawa S, Kaneko S, Kawasaki S, Matsuyama Y, Okazaki M, Okita K, Omata M, Saida Y, Takayama T and Yamaoka Y: Development of evidence-based clinical guidelines for the diagnosis and treatment of hepatocellular carcinoma in japan. Hepatol Res 38(1): 37-51, 2008.

7 Imai K, Beppu T, Chikamoto A, Doi K, Okabe H, Hayashi H, Nitta H, Ishiko T, Takamori $\mathrm{H}$ and Baba $\mathrm{H}$ : Comparison between hepatic resection and radiofrequency ablation as first-line treatment for solitary small-sized hepatocellular carcinoma of 3 cm or less. Hepatol Res 43(8): 853-864, 2013.

8 Liu JG, Wang YJ and Du Z: Radiofrequency ablation in the treatment of small hepatocellular carcinoma: A meta analysis. World J Gastroenterol 16(27): 3450-3456, 2010.

9 Nitta H, Nakagawa S, Kaida T, Arima K, Higashi T, Taki K, Okabe H, Hayashi H, Hashimoto D, Chikamoto A, Ishiko T, Beppu T and Baba H: Pre-treatment double- or triple-positive tumor markers are predictive of a poor outcome for patients undergoing radiofrequency ablation for hepatocellular carcinoma. Surg Today 47(3): 375-384, 2017.

10 Cho YK, Kim JK, Kim WT and Chung JW: Hepatic resection versus radiofrequency ablation for very early-stage hepatocellular carcinoma: A markov model analysis. Hepatology 51(4): 12841290, 2010.

11 Molinari $M$ and Helton S: Hepatic resection versus radiofrequency ablation for hepatocellular carcinoma in cirrhotic individuals not candidates for liver transplantation: A markov model decision analysis. Am J Surg 198(3): 396-406, 2009.

12 Livraghi T, Meloni F, Di Stasi M, Rolle E, Solbiati L, Tinelli C and Rossi S: Sustained complete response and complications rates after radiofrequency ablation of very early hepatocellular carcinoma in cirrhosis: Is resection still the treatment of choice? Hepatology 47(1): 82-89, 2008.

13 Park W, Chung YH, Kim JA, Jin YJ, Lee D, Shim JH, Lee D, Kim KM, Lim YS, Lee HC, Lee YS, Kim PN and Sung KB: Recurrences of hepatocellular carcinoma following complete remission by transarterial chemoembolization or radiofrequency therapy: Focused on the recurrence patterns. Hepatol Res 43(12): 1304-1312, 2013.

14 Ding J, Jing X, Liu J, Wang Y, Wang F, Wang Y and Du Z: Comparison of two different thermal techniques for the treatment of hepatocellular carcinoma. Eur J Radiol 82(9): 1379-1384, 2013.

15 Hori T, Nagata K, Hasuike S, Onaga M, Motoda M, Moriuchi A, Iwakiri H, Uto H, Kato J, Ido A, Hayashi K and Tsubouchi $\mathrm{H}$ : Risk factors for the local recurrence of hepatocellular carcinoma after a single session of percutaneous radiofrequency ablation. J Gastroenterol 38(10): 977-981, 2003. 
16 Kono M, Inoue T, Kudo M, Chishina H, Arizumi T, Takita M, Kitai S, Yada N, Hagiwara S, Minami Y, Ueshima K, Nishida N and Murakami T: Radiofrequency ablation for hepatocellular carcinoma measuring $2 \mathrm{~cm}$ or smaller: Results and risk factors for local recurrence. Dig Dis 32(6): 670-677, 2014.

17 Masuda T, Beppu T, Ishiko T, Horino K, Baba Y, Mizumoto T, Hayashi H, Okabe H, Horlad H, Doi K, Okabe K, Takamori H, Hirota M, Iyama $\mathrm{K}$ and Baba $\mathrm{H}$ : Intrahepatic dissemination of hepatocellular carcinoma after local ablation therapy. J Hepatobiliary Pancreat Surg 15(6): 589-595, 2008.

18 Mima K, Hayashi H, Imai K, Kuroki H, Nakagawa S, Okabe H, Chikamoto A, Watanabe M, Beppu T and Baba H: High CD44s expression is associated with the emt expression profile and intrahepatic dissemination of hepatocellular carcinoma after local ablation therapy. J Hepatobiliary Pancreat Sci 20(4): 429434, 2013.

19 Llovet JM, Vilana R, Bru C, Bianchi L, Salmeron JM, Boix L, Ganau S, Sala M, Pages M, Ayuso C, Sole M, Rodes J and Bruix $\mathrm{J}$ : Increased risk of tumor seeding after percutaneous radiofrequency ablation for single hepatocellular carcinoma. Hepatology 33(5): 1124-1129, 2001.

20 Doi K, Beppu T, Ishiko T, Chikamoto A, Hayashi H, Imai K, Nitta H, Baba Y, Masuda T, Okabe K, Kuramoto M, Kudo K, Ogata K, Ohchi T, Takamori H, Kikuchi $\mathrm{K}$ and Baba H: Endoscopic radiofrequency ablation in elderly patients with hepatocellular carcinoma. Anticancer Res 35(5): 3033-3040, 2015.

21 Dindo D, Demartines $\mathrm{N}$ and Clavien PA: Classification of surgical complications: A new proposal with evaluation in a cohort of 6336 patients and results of a survey. Ann Surg 240(2): 205-213, 2004.
22 Hasegawa K, Kokudo N, Makuuchi M, Izumi N, Ichida T, Kudo M, Ku Y, Sakamoto M, Nakashima O, Matsui O and Matsuyama Y: Comparison of resection and ablation for hepatocellular carcinoma: A cohort study based on a Japanese Nationwide Survey. J Hepatol 58(4): 724-729, 2013.

23 Tateishi R, Shiina S, Akahane M, Sato J, Kondo Y, Masuzaki R, Nakagawa H, Asaoka Y, Goto T, Otomo K, Omata M, Yoshida H and Koike K: Frequency, risk factors and survival associated with an intrasubsegmental recurrence after radiofrequency ablation for hepatocellular carcinoma. PLoS One 8(4): e59040, 2013.

24 Shiina S, Tateishi R, Arano T, Uchino K, Enooku K, Nakagawa H, Asaoka Y, Sato T, Masuzaki R, Kondo Y, Goto T, Yoshida H, Omata $\mathrm{M}$ and Koike $\mathrm{K}$ : Radiofrequency ablation for hepatocellular carcinoma: 10-year outcome and prognostic factors. Am J Gastroenterol 107(4): 569-577; quiz 578, 2012.

25 Yamashita Y, Tsuijita E, Takeishi K, Fujiwara M, Kira S, Mori M, Aishima S, Taketomi A, Shirabe K, Ishida T and Maehara Y: Predictors for microinvasion of small hepatocellular carcinoma $</=2 \mathrm{~cm}$. Ann Surg Oncol 19(6): 2027-2034, 2012.

26 Hasegawa K, Kokudo N, Shiina S, Tateishi R and Makuuchi M: Surgery versus radiofrequency ablation for small hepatocellular carcinoma: Start of a randomized controlled trial (surf trial). Hepatol Res 40(8): 851-852, 2010.

Received November 5, 2017

Revised November 22, 2017

Accepted November 28, 2017 